\title{
Interactive physiological response of potato (Solanum tuberosum L.) plants to fungal colonization and Potato virus Y (PVY) infection
}

\author{
Dominika Thiem ${ }^{1}$, Adriana Szmidt-Jaworska², Christel Baum³ ${ }^{3}$ Katja Muders ${ }^{4}$, \\ Katarzyna Niedojadło ${ }^{5}$, Katarzyna Hrynkiewicz ${ }^{1 *}$ \\ ${ }^{1}$ Department of Microbiology, Faculty of Biology and Environment Protection, N. Copernicus University, Lwowska 1, 87-100 Toruń, Poland \\ ${ }^{2}$ Chair of Plant Physiology and Biotechnology, Faculty of Biology and Environment Protection, N. Copernicus University, Lwowska 1, 87-100 \\ Toruń, Poland \\ ${ }^{3}$ Soil Science, University of Rostock, Justus-von-Liebig-Weg 6, D-18059 Rostock, Germany \\ ${ }^{4}$ Norika - Nordring Kartoffelzucht- und Vermehrungs GmbH, Parkweg 4, D-18190 Groß Lüsewitz, Germany \\ ${ }^{5}$ Department of Cell Biology, Faculty of Biology and Environment Protection, N. Copernicus University, Lwowska 1, 87-100 Torun, Poland
}

\section{Abstract}

Potato plants can be colonized by various viruses and by symbiotic, saprophytic and pathogenic fungi. However, the significance of interactions of viral infection and fungal colonization is hardly known. This work presents a model experiment in which the influence of three different types of fungal associations on the growth and physiology of the potato variety Pirol was tested individually or in combination with infection by PVY. It was hypothesized that simultaneous viral and fungal infections increase the biotic stress of the host plant, but mutualistic plant-fungal associations can mask the impact of viral infection. In the present study, a symbiotic arbsucular mycorrhizal fungus, Glomus intraradices, significantly stimulated the growth of plants infected with PVY. In contrast, two saprophytic Trichoderma spp. strains either did not influence or even inhibited the growth of PVY-infected plants. Also, inoculation of PVY-infected potato plants with a pathogenic strain of Colletotrichum coccodes did not inhibit the plant growth. Growth of the PVY-free potato plants was not promoted by the symbiotic fungus, whereas T. viride, T. harzianum and C. coccodes had an evident inhibitory effect. The strongest growth inhibition and highest concentration of $\mathrm{H}_{2} \mathrm{O}_{2}$, as an indicator of biotic stress, was observed in PVY-free potato plants inoculated with T. harzianum and C. coccodes strains. Surprisingly, ultrastructural analysis of PVY-infected plant roots colonized by $G$. intraradices showed virus-like structures in the arbuscules. This pointed to the possibility of mycorrhizal-mediated transmission of virus particles and has to be further

\footnotetext{
*Corresponding author. Email: hrynk@umk.pl

Handling Editor: Tomasz Leski
} 
examined by testing with immunoassays and real transmission to uninfected plants. In conclusion, although mycorrhiza formation might decrease the impact of PVY infection on plants, a possible role of mycorrhizal fungi as virus vectors is discussed.

Keywords: biotic stress; Potato virus Y (PVY); Glomus intraradices; Trichoderma viride; T. harzianum; Colletotrichum coccodes

\section{Introduction}

Potato virus $\mathrm{Y}$ (PVY) represents the most important taxonomic group of viral pathogens infecting potato (Solanum tuberosum L.). It can reduce the quality of the crop and may cause yield losses up to $80 \%$ [1]. Several PVY strain groups are distinguished, each of them causing different symptoms, such as mosaicism, veinal necrosis, leaf spots and systemic necrosis. Some strains can also evoke tuber necrosis, particularly in sensitive potato varieties [2]. High infectivity of PVY is attributed both to its high genetic variability and cultivation of susceptible plant cultivars. Transmission of the virus between host plants takes place mainly by aphids, arthropods, nematodes, fungi (mostly obligate parasites), or plasmodiophorid vectors $[1,3,4]$, although incidentally it may be also transmitted mechanically.

Plants grown under high infection pressure can only be protected from infection by a consequent use of insecticides [5]. Meanwhile, a number of plant-associated microorganisms can reduce the negative impact of plant pathogens [6-8]. These include arbuscular fungi, symbionts of many crops, which can stimulate the absorption of water and nutrients from the soil - mainly phosphorus $(\mathrm{P})$ and nitrogen $(\mathrm{N})$, and increase tolerance to abiotic and resistance to biotic stress factors, e.g., pathogen infections [9]. Similar properties have also been reported for strains of some saprotrophic Trichoderma spp. [10]. Some strains of this genus have the ability to synthesize a number of secondary metabolites, such as plant hormones and vitamins, and can increase the availability of nitrogen $(\mathrm{N})$ and phosphorus $(\mathrm{P})$ or other plant nutrients. As a result, they can stimulate plant growth and productivity in either the presence or absence of other microorganisms and compete with pathogenic soil microorganisms [11]. Some Trichoderma strains exhibit antibiosis and mycoparasitism activities, which may lead to the reduction of plant pathogen populations [6]. It has been shown that saprophytic Trichoderma spp. releases elicitors during colonization of plant roots, which activate defense pathways of the host plant, thus protecting it against pathogen infection [6]. However, antiviral effects of saprophytic fungi have not been elucidated so far. Apart from the fungi promoting plant growth, there is also a large group of pathogenic fungi that colonize potato plants. These fungi can synthesize enzymes and toxins that damage plant cells or interrupt the hormonal regulation of plant growth. Among them, Colletotrichum coccodes, the causal agent of potato black dot, produces characteristic symptoms by formation of microsclerotia that prevail in host tissues in the late growing season [12]. Pathogenic microorganisms may increase the level of reactive oxygen species (ROS) in plant cells, which interferes with the metabolic processes and activates plant defense responses. Such a plant response to pathogen infection was observed both for fungi and viruses [13]. 
In the present work, the effects of fungal colonization of PVY-infected (PVY+) and non-PVY-infected (PVY-) potato plants are tested in a model experiment. The tested fungi represent three ecological groups: symbiotic - Glomus intraradices, saprotrophic - Trichoderma viride and T. harzianum, and pathogenic Colletotrichum coccodes. The level of $\mathrm{H}_{2} \mathrm{O}_{2}$ in the leaves served as an indicator of the stress level for PVY+ and PVYplants. Additionally, fungal hyphae were examined microscopically for the intracellular presence of virus particles.

\section{Material and methods}

\section{Plant and microbial material}

Tubers of potato cv. Pirol (Norika GmbH, Sanitz, Germany) were used in the experiments, which was selected as model plant, since it is described to be medium resistant to infection by PVY and fungal pathogens. PVY infection of each tuber as well as the absence of the virus in the control material (PVY- tubers) were confirmed by ELISA. Sprouting tubers were inoculated individually by four fungal strains, differing in the impact on growth and development of potato plants: symbiotic - G. intraradices in the form of mycorrhizal inoculum (INOQ, GmbH, Institut für Pflanzenkultur, Germany), saprophytic - T. viride DAR5 (collection of the University of Rostock, Germany) and T. harzianum K116 (collection of the N. Copernicus University, Torun, Poland), and pathogenic - C. coccodes K116 (collection of the Norika GmbH, Germany).

\section{Pot experiment}

Potato tubers were placed in polyethylene pots filled with sterile mixture of soil and vermiculite (1:1, v:v, $1 \mathrm{~kg}$ mixture in each pot). In the trial, 15 tubers infected with PVY and 15 control tubers (non-PVY-infected) were used. The experiment was conducted in a growth chamber under a sodium lighting system $\left[100 \mu \mathrm{mol} \mathrm{m} \mathrm{m}^{-2} \mathrm{~s}^{-1}\right.$ PAR (photosynthetically active radiation), temp. $24^{\circ} \mathrm{C}, 16 \mathrm{~h}$ light and $8 \mathrm{~h}$ darkness].

Inoculum samples of T. viride DAR5, T. harzianum and C. coccodes K116 strains were prepared in petri dishes on PDA medium (Potato Dextrose Agar, Difco). Strains were cultivated for 7 days at $23^{\circ} \mathrm{C}$. Afterwards, each fungal inoculum with an adjacent small amount of agar was transferred with a sterile scalpel onto the sprouting tubers. A sample of the mycorrhizal G. intraradices fungus (spores and hyphae) was introduced in a mixture with sand and vermiculite used in the recommended by the manufacturer amount $-20 \mathrm{ml} /$ pot. Inoculation of plants was repeated after a period of two weeks to enhance the effect of fungal inoculation. For each plant treatment, the following inoculation variants were performed: non-inoculated control, inoculated with: G. intraradices, T. viride DAR5, T. harzianum and C. coccodes (3 replicates for each variant). This pattern of inoculation was used both for PVY-infected and non-PVY-infected plants (30 plants in total). The plants were watered with sterile distilled water. After a 10-week growth period, the plants were harvested and divided into roots, stems and leaves. Leaves and roots (100 mg per each treatment) were frozen in liquid nitrogen for subsequent determination of the hydrogen peroxide $\left(\mathrm{H}_{2} \mathrm{O}_{2}\right)$ content. The rest of the plant biomass (roots, stems and leaves) was dried at $65^{\circ} \mathrm{C}$ until constant weight was achieved and weighed. 


\section{Determination of hydrogen peroxide $\left(\mathrm{H}_{2} \mathrm{O}_{2}\right)$ level}

Analysis of $\mathrm{H}_{2} \mathrm{O}_{2}$ level in plant tissues (leaves, roots) was performed using the PeroxiDetectTM Kit for determination of aqueous and lipid hydroperoxides (Sigma, Saint Louis, Missouri 63103 USA), according to the manufacturer's protocol. The level of hydrogen peroxide was expressed as $\mathrm{nmol} / \mathrm{g}$ of tissue according to the following formula: nmol of peroxide $/ \mathrm{g}$ of plant tissue $=[($ A560 - A560 control sample $) \times$ dilution $] /[$ A560 $(1 \mathrm{nmol}$ peroxide) $\times$ volume of sample].

\section{Electron microscopy analysis}

Small pieces of plant root tissue inoculated with G. intraradices were fixed overnight at $4^{\circ} \mathrm{C}$ with $2.5 \%$ glutaraldehyde in $0.1 \mathrm{M}$ phosphate-buffered saline (PBS, $\mathrm{pH}$ 7.2). The first hour of fixation was carried out in a vacuum pump at $4^{\circ} \mathrm{C} \mathrm{[12].} \mathrm{After} \mathrm{washing} \mathrm{in}$ PBS (pH 7.2), the sample was postfixed with $1 \% \mathrm{OsO}_{4}$ in $\mathrm{PBS}(\mathrm{pH} 7.2)$ for 2 hours at $4^{\circ} \mathrm{C}$. Samples were washed, dehydrated in graded concentrations of ethanol up to $100 \%$ and embedded in LR Gold (Sigma) with $1 \%$ benzoyl peroxide as a polymerization accelerator and polymerized at $4^{\circ} \mathrm{C}$ for $24 \mathrm{~h}$ days. Ultrathin longitudinal sections were cut using a Leica UTC ultramicrotome, collected on nickel grids coated with $0.3 \%$ Formvar (Sigma) and stained with $1 \%$ phosphotungstic acid and 5\% uranyl acetate solutions. Sections were examined using a Joel EM 1010 transmission electron microscope.

\section{Statistical analysis}

Results of the pot experiment were statistically analyzed using the Student's $t$-test to evaluate the differences in biomass production (leaves, stems and roots) between control plants (non-inoculated) and plants inoculated with four different fungal strains. Two-factor ANOVA and Newman-Keuls multiple range test ( $P \leq 0.05$; for comparison of means) were used to compare the effects of inoculation on biomass production of PVY+ and PVYplants. All statistical analyses were performed using Statistica for Windows, version 7.0.

\section{Results}

Impact of mycorrhizal, saprotrophic and pathogenic fungi on the growth of PVY-infected and non-PVY-infected potato cv. Pirol plants

Fungal strains used for inoculation differed in their effects on PVY-infected and nonPVY-invected plants. Only the mycorrhizal fungus G. intraradices increased the growth of PVY(+) plants compared to the uninoculated control plants. Significant differences were recorded for the dry weight of leaves and stems (Fig. 1a-c). The other fungal strains either inhibited (T. viride; leaves and roots) or did not affect (T. harzianum and C. coccodes) the growth parameters of PVY(+) potato plants. Remarkably, no growth promotion of PVY(-) plants by the mycorrhizal treatment was observed. The non-mycorrhizal T. viride, T. harzianum and C. coccodes fungal strains decreased the growth of PVY(-) potato plants, especially the development of leaves and stems. However, the two-way ANOVA statistical analysis (Tab. 1) only showed a significant effect of PVY infection in respect to the dry weight of stems. Dry weight of leaves and stems, but not of roots, was significantly affected in plants inoculated with all selected fungal strains. However, 
statistically significant reduction of dry weight of leaves and stems was only observed for plants treated with saprophytic strains T. viride or T. harzianum.
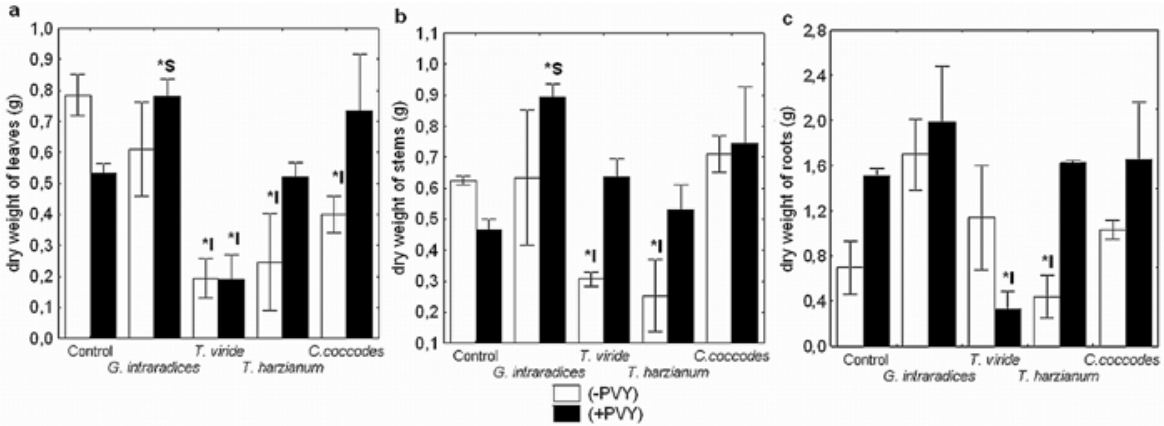

Fig. 1 Impact of Glomus intraradices, Trichoderma viride, T. harzianum and Colletotrichum coccodes inoculation on the dry weight of leaves (a), stems (b) and roots (c) of PVY-infected (PVY+) or virus-free (PVY-) plants of potato cv. Pirol (Student test, $n=3, \pm S D$ ). S - stimulation; I - inhibition.

Tab. 1 The effects of interaction between two factors: infection of plants with virus particles $[(+\mathrm{PVY})$ and (-PVY)] and inoculation of plants with fungi (Glomus intraradices, Trichoderma viride, T. harzianum, Colletotrichum coccodes) on the biomass production (leaves, stems and roots) in plants of potato $\mathrm{cv}$. Pirol (ANOVA2; $P \leq 0.05$ ).

1. Virus

\begin{tabular}{ccccccccc}
\multicolumn{3}{c}{ LEAVES } & \multicolumn{4}{c}{ SHOOTS } & \multicolumn{3}{c}{ ROOTS } \\
\hline $\begin{array}{c}\text { MS } \\
\text { effect }\end{array}$ & $\boldsymbol{F}$ & $\boldsymbol{P}$ & $\begin{array}{c}\text { MS } \\
\text { effect }\end{array}$ & $\boldsymbol{F}$ & $\boldsymbol{P}$ & $\begin{array}{c}\text { MS } \\
\text { effect }\end{array}$ & $\boldsymbol{F}$ & $\boldsymbol{P}$ \\
\hline 0.0886 & 2.8084 & 0.1093 & 0.1658 & 4.9079 & $0.0385^{*}$ & 0.2253 & 0.3071 & 0.5856 \\
0.2698 & 8.5557 & $0.0003^{*}$ & 0.1556 & 4.6073 & $0.0084^{*}$ & 1.1529 & 1.5712 & 0.2206 \\
0.0789 & 2.5029 & 0.0749 & 0.0633 & 1.8745 & 0.1544 & 0.6170 & 0.8409 & 0.5155
\end{tabular}

2. Inoculation 0.0789

\section{Newman-Keuls test}

\section{Virus}

\begin{tabular}{llll}
\hline $\operatorname{PVY}(-)$ & $0.4470^{\mathrm{a}}$ & $0.5057^{\mathrm{a}}$ & $1.2470^{\mathrm{a}}$ \\
$\operatorname{PVY}(+)$ & $0.5557^{\mathrm{a}}$ & $0.6543^{\mathrm{b}}$ & $1.4203^{\mathrm{a}}$
\end{tabular}

\section{Inoculation}

\begin{tabular}{llll}
\hline Control & $0.6692^{\mathrm{b}}$ & $0.5458^{\mathrm{ab}}$ & $1.1025^{\mathrm{a}}$ \\
G. intraradices & $0.6950^{\mathrm{b}}$ & $0.7633^{\mathrm{b}}$ & $1.8433^{\mathrm{a}}$ \\
T. viride & $0.1917^{\mathrm{a}}$ & $0.4717^{\mathrm{ab}}$ & $0.7350^{\mathrm{a}}$ \\
T. harzianum $_{\text {coccodes }}$ & $0.3833^{\mathrm{ab}}$ & $0.3917^{\mathrm{a}}$ & $1.6450^{\mathrm{a}}$ \\
C. & $0.5675^{\mathrm{b}}$ & $0.7275^{\mathrm{b}}$ & $1.3425^{\mathrm{a}}$ \\
\hline
\end{tabular}




\section{Analysis of the stress level after PVY infection and fungal association \\ - determination of hydrogen peroxide $\left(\mathrm{H}_{2} \mathrm{O}_{2}\right)$ level}

After fungal inoculation, $\mathrm{PVY}(+)$ and $\mathrm{PVY}(-)$ plants differed in the $\mathrm{H}_{2} \mathrm{O}_{2}$ concentrations when compared with control plants. The highest level of hydrogen peroxide was recorded for leaves of plants inoculated with T. viride and C. coccodes (Fig. 2a). For both above types of inoculation, leaves of PVY $(+)$ plants revealed 1.4-2.4-fold higher amounts of $\mathrm{H}_{2} \mathrm{O}_{2}$ than leaves of $\mathrm{PVY}(-)$ plants. The elevated $\mathrm{H}_{2} \mathrm{O}_{2}$ level in leaves of $T$. viride-inoculated plants was correlated with a significant decrease in the leaf biomass (Fig. 1a and Tab. 1). Such a relationship was not observed after inoculation of plants with C. coccodes. The plants inoculated with $G$. intraradices and T. harzianum only showed a slightly higher $\mathrm{H}_{2} \mathrm{O}_{2}$ level compared to leaves of non-inoculated control plants.

The $\mathrm{H}_{2} \mathrm{O}_{2}$ profile in the roots differed from that observed in the leaves (Fig. 2b). Both PVY(+) and PVY(-) plant roots inoculated with G. intraradices exhibited similar $\mathrm{H}_{2} \mathrm{O}_{2}$ concentrations compared to the non-inoculated variant. Inoculation with T. harzianum resulted in a decrease in $\mathrm{H}_{2} \mathrm{O}_{2}$ level in the roots of $\mathrm{PVY}(-)$ plants, whereas the $\mathrm{PVY}(+)$ plants showed the same level of this compound as did the control plants. Inoculations with T. viride and C. coccodes resulted in a similar way, increasing the level of $\mathrm{H}_{2} \mathrm{O}_{2}$ in $\mathrm{PVY}(-)$ plant roots and decreasing the level of this compound in PVY(+) plant roots (Fig. 2b).
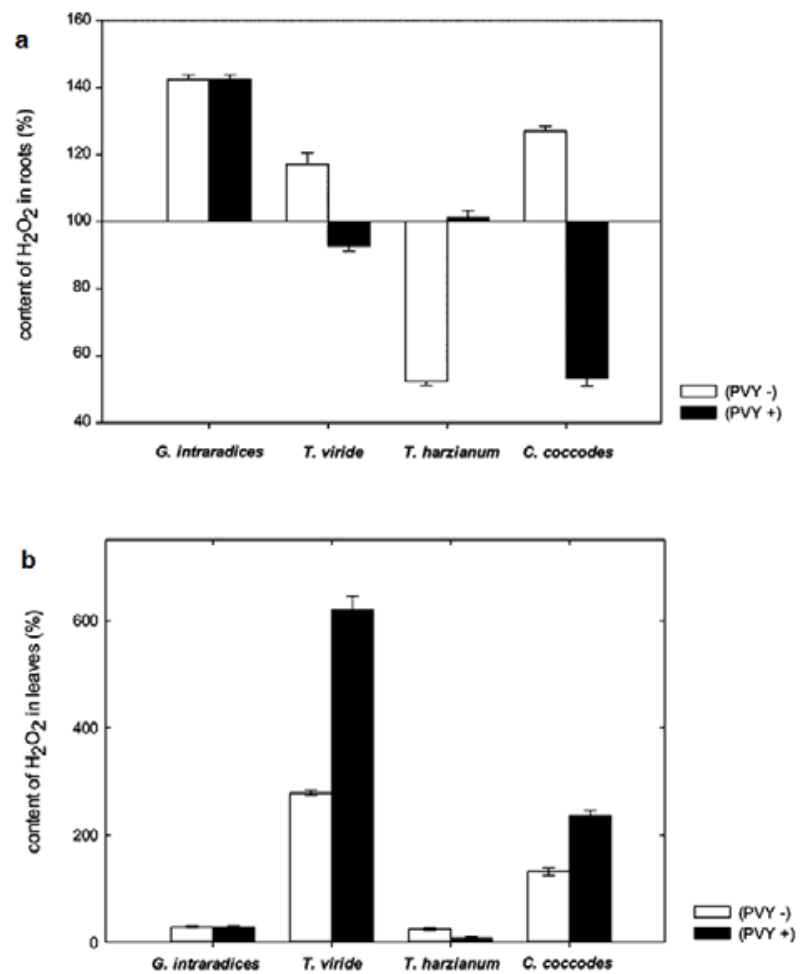

Fig. 2 Impact of Glomus intraradices, Trichoderma viride, T. harzianum and Colletotrichum coccodes inoculation on the production of hydrogen peroxide in leaves $(\mathbf{a})$ and roots $(\mathbf{b})$ of $\mathrm{PVY}(+)$ and PVY (-) plants of potato cv. Pirol. The level of hydrogen peroxide is presented as a percentage of stimulation or inhibition in relation to the control (100\%; mean value $\pm S D$ ). 


\section{Correlation of plant growth parameters and $\mathrm{H}_{2} \mathrm{O}_{2}$ level}

Growth parameters (dry weight of leaves, stems and roots) of PVY $(+) \mathrm{cv}$. Pirol plants were analyzed in relation to the $\mathrm{H}_{2} \mathrm{O}_{2}$ levels in leaves and roots. A significant negative correlation was found between the dry weight of roots and $\mathrm{H}_{2} \mathrm{O}_{2}$ level in the leaves $(r=-0.94, P=0.02$; Fig. 3a). A similar relationship was observed for the dry weight and $\mathrm{H}_{2} \mathrm{O}_{2}$ level in leaves, but it was not statistically significant (data not shown).

In contrast, a significant positive correlation between dry weight and $\mathrm{H}_{2} \mathrm{O}_{2}$ level in the roots of PVY(-) plants was found (Fig. 3b). Remarkably, the level of $\mathrm{H}_{2} \mathrm{O}_{2}$ in leaves or roots had no impact on the biomass of stems. This observation suggests that stems are not involved in the reaction of plants. Perhaps, this organ plays a role as a transmitter of signals between the above- and below-ground parts of the plants.
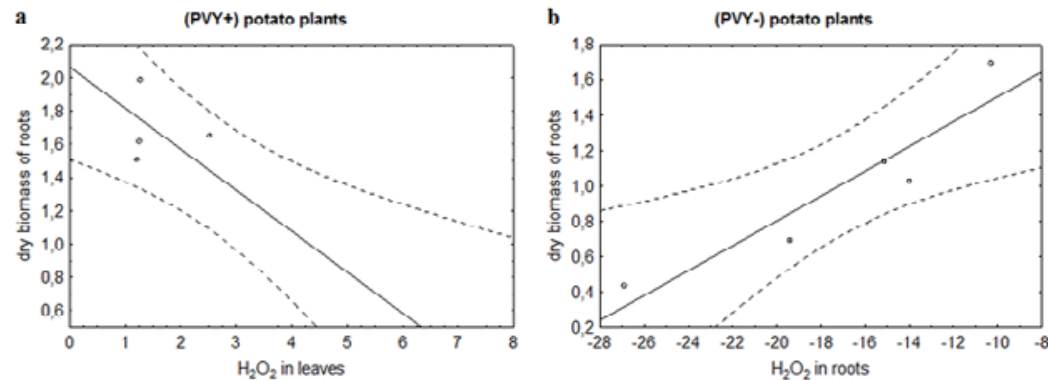

Fig. 3 Correlation of growth parameters of PVY(+) and PVY(-) plants of potato cv. Pirol with the $\mathrm{H}_{2} \mathrm{O}_{2}$ level in leaves and roots.

\section{Observation of PVY particles in hyphae of $G$. intraradices}

The results of ultrastructural analysis confirmed the presence of hyphae of G. intraradices penetrating the intracellular spaces of potato roots (Fig. $4 \mathrm{a}-\mathrm{c}$ ), thus confirming an effective colonization process. This symbiotic fungus formed unique structures, such as arbuscules and vesicles in the roots. In addition, numerous bacterial cells were observed inside the plant cells (Fig. 4c,d). They were mostly concentrated around the fungal coils, or (rarely) distributed along the cell wall of the host plant. Fig. 4a and Fig. 4b depict structures similar to virus particles visible inside the hyphae forming arbuscules. Fig. $4 \mathrm{~d}$ shows the concentration of described above virus-like particles around bacterial cell clusters.

\section{Discussion}

Mutual relationships between two (or more) pathogens and/or symbionts in the same host plant are hardly to assess in their total diversity and significance. Therefore the present study is a pilot model to indicate general processes in this interaction by a selected combination of one potato variety with one virus and four fungal strains only. We demonstrate significant stimulation of growth of PVY-infected potato plants inoculated with the mycorrhizal $G$. intraradices fungus. Our results are opposite to the observations of Sipahioglu et al. [14] who revealed significantly greater reduction in plant height and 

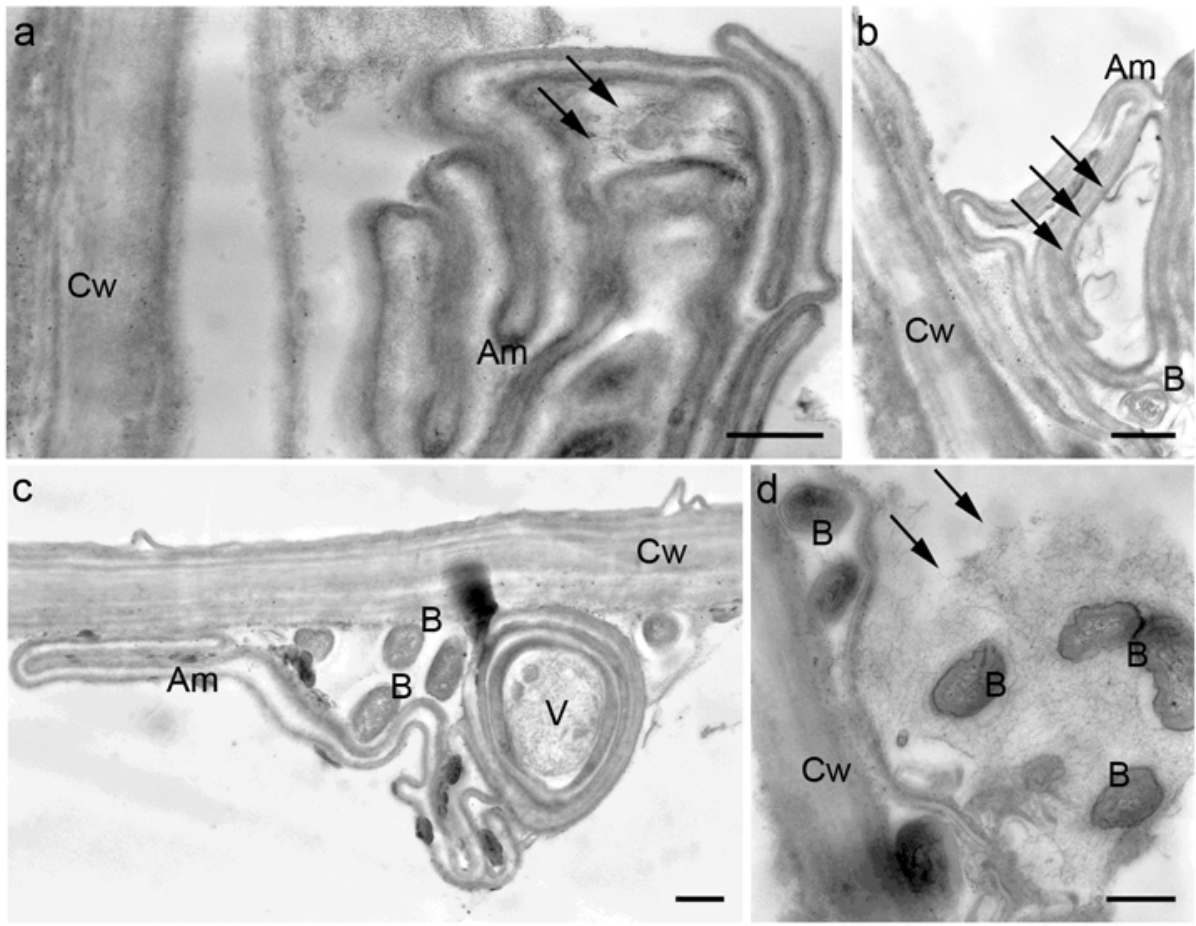

Fig. 4 Electron microscope (TEM) micrographs of the roots of potato cv. Pirol infected with PVY particles and inoculated with Glomus intraradices. Am - mycelium of arbuscular fungus; $\mathrm{Cw}$ - cell wal; V - vesicules; B - bacteria. Viral-like particles are marked with arrows. Bar: $500 \mathrm{~nm}$.

root development in PVY-infected potato plants inoculated with G. intraradices. It is known that potato plants are colonized by arbuscular fungi can promote plant growth (e.g., Bayrami et al. [15]). However, in the present study, a significant effect of mycorrhization on the growth of healthy potato plants was only observed in the roots. It is well known that mycorrhiza formation can lead to growth promotion by increased supply of water and nutrients [16]. Furthermore, promotion of plant growth might favors virus multiplication. Increased multiplication of plant viruses by mycorrhizal colonization of the host plants was revealed previously [17]. Yet, only one report [18] showed the enhanced disease severity compared with non-mycorrhizal controls. Based on investigations involving three viruses (Tomato acuba mosaic virus, Potato virus $X$, Arabis mosaic virus) in three different hosts (tomato, petunia, strawberry), Daft and Okusanya [17] revealed that the amount of extractable virus particles is higher for mycorrhizal than non-mycorrhizal plants. They suggested that this is due to the high phosphate level in mycorrhizal plants. Enhanced virus multiplication was also observed for non-mycorrhizal plants grown under increased supply of soluble phosphate [17]. Besides, colonization of roots by mycorrhizal fungi was reported to increase the ability of plants to activate defense processes during pathogen infection [9]. It has been shown that physical contact of arbuscular fungi with 
plant roots can affect the expression of genes involved in the defense system [7,9]. During the infection process, cells of mycorrhized plants were determined to exhibit an increased level of antioxidant enzymes and pathogenesis-related (PR) proteins [9]. Furthermore, mycorrhized plants were found to express increased resistance against pathogens, e.g., Capsicum annuum against infection with Phytophthora capsici [19], or Medicago truncatula against the bacterial pathogen Xanthomonas campestris [7]. Meanwhile, the number of reports supporting the existence of a protective effect of mycorrhizal fungi on plants infected with viruses is still scarce.

Beside mycorrhizal fungi, several saprotrophic fungal species like Trichoderma spp. show plant growth promoting capacities, such as synthesis of plant hormones and vitamins as well as increased intensity of nutrient uptake from soil (e.g., $\mathrm{N}$ and P) [6]. However, in our experiments both T. harzianum and $T$. viride strains significantly inhibited the growth of PVY $(+)$ and PVY $(-)$ control plants. The observed growth inhibition of potato plants by Trichoderma strains might have been caused by temporal nutrient competition or plant species-specific effects. Such differences, due to colonization with Trichoderma strains, have been reported earlier for tomato and cucumber [10].

So far there is no knowledge on the resistance of potato to black dot caused by the C. coccodes fungus. Here, the influence of this pathogen on virus-infected potato plants was investigated for the first time. In our study, $C$. coccodes significantly decreased the dry weight of leaves of PVY(-) plants, but had no significant effect on PVY $(+)$ plants. As $C$. coccodes infection starts in below-ground plant organs and spreads into the above-ground stems [20], we suggest that PVY infection might delay the dissemination of the fungus into the upper plant parts, e.g. by stronger or earlier activation of defense mechanisms in the plant.

In the present study, slightly increased concentrations of foliar hydrogen peroxide $\left(\mathrm{H}_{2} \mathrm{O}_{2}\right)$ were noted in mycorrhized plants compared to the non-mycorrhizal control. The mechanism by which the mycorrhizal fungi induce resistance in plants is still unclear [19]. It is known that some of the genes responsible for the formation of mycorrhizal symbiosis are activated during pathogen infection [7,9]. In both cases, changes in the synthesis of ROS were observed [17]. Vasse et al. [21] revealed that ROS are generated in response to all plant-invading microorganisms (also symbiotic), and react with the defensive response as long as the symbiont is not recognized as such [21]. Moreover, it was observed that development of the mutualistic association between the fungal endophyte - Epichloë festucae, and its host plant (Lolium perenne) requires production of superoxide or hydrogen peroxide by a fungal NADPH oxidase, while inactivation of this gene changes the fungi-host interaction from mutualistic to antagonistic [22]. The level of $\mathrm{H}_{2} \mathrm{O}_{2}$ in mycorrhized plants was not affected by PVY infection, although various types of abiotic and biotic stress can lead to an uncontrolled increase of ROS formation, leading both to damage of biomolecules and activation of defense mechanisms [13]. In the cells of mycorrhized plants, the $\mathrm{H}_{2} \mathrm{O}_{2}$ level after inoculation with a pathogen may decrease compared to non-mycorrhized plants [19]. Literature data shows that the highest $\mathrm{H}_{2} \mathrm{O}_{2}$ level in mycorrhized plants infected with pathogens can be observed already after $6 \mathrm{~h}$, while in non-mycorrhized plants after $12 \mathrm{~h}$ [19]. This indicates a faster induction of defense mechanisms in mycorrhized plants. Since in our study the level of $\mathrm{H}_{2} \mathrm{O}_{2}$ was tested 10 weeks after plant inoculation, any potential factors contributing to induction of resistance would have already acted. The effect of mycorrhization of Solanum lycopersicum 
plants on the infection process with tomato spotted wilt virus (TSWV) suggests that mycorrhizae may cause suppression of plant response to viral infection [23]. Mycorrhizal symbiosis was shown to decrease expression of genes activated during viral infection and reduce visual symptoms in long-term [23]. Similarly, in our study growth promotion of virus-infected plants in mycorrhizal symbiosis was observed.

Beside the mycorrhizal effects, it was determined that inoculation of potato plants with T. viride significantly stimulated the formation of reactive oxygen species; yet this was not correlated with plant growth promotion. Participation of Trichoderma sp. in enhancement of plant resistance against pathogens by activating the defence response was earlier shown by Nawrocka et al. [10]. Trichoderma spp. can affect other soil microorganisms, e.g. by antibiosis [4]. Some antibiotics synthesized by microorganisms may be active against viruses $[6,24]$. As was shown previously, some peptide antibiotics synthesized by Trichoderma sp. can significantly reduce the development of TMV in tobacco plants (Nicotiana tabacum) [24]. It was suggested that an increased level of reactive oxygen species, like we observed in our study, might indicate that substances synthesized by fungi induce immunity in the infected plants.

Infection of $S$. tuberosum $\mathrm{L}$. with the pathogenic $C$. coccodes significantly increased the $\mathrm{H}_{2} \mathrm{O}_{2}$ level in the leaves of both PVY(+) and PVY(-) plants compared to the non-inoculated control. This effect is suggested to be due to the activation of the ROS synthesis in response to pathogen infection [25]. Specifically, this could be caused by secretion of ammonium (as the source of deamination of amino acids), which in turn can lead to alkalization of the environment from $\mathrm{pH} 4.2$ to 7.9, during all growth stages of Colletotrichum spp. [26]. Ammonium secreted by C. coccodes can enhance ROS accumulation, promoting cell death and fungal virulence [26]. Moreover, it was shown that ammonium indirectly activates the transport of various host solutes, modulates concentrations of host cytosolic protons [27], and alters the membrane flux processes [28].

As the level of $\mathrm{H}_{2} \mathrm{O}_{2}$ in our experiment was tested 10 weeks after plant inoculation, it could be that the highest accumulation of $\mathrm{H}_{2} \mathrm{O}_{2}$ in plants appeared much earlier. Literature data reports that increased levels of $\mathrm{H}_{2} \mathrm{O}_{2}$ in plants after contact with fungi, can initiate adequate defense mechanisms, called "fast reaction" [29]. In the absence of an appropriate fungal signal, a prolonged infection process and consistently high $\mathrm{H}_{2} \mathrm{O}_{2}$ concentrations induce a permanent stress reaction. In such a situation, a microorganism is recognized as incompatible [30]. Based on the gathered data, we speculate that the specific features of each fungal strain rather than colonization per se play a key role in the plant response related to $\mathrm{H}_{2} \mathrm{O}_{2}$. Moreover, it seems that the antioxidant systems lead to different colonization strategies depending on the fungal strain involved. A constantly high $\mathrm{H}_{2} \mathrm{O}_{2}$ concentration is probably the main toxic factor during stress conditions that contributes to the decreased biomass production [31]. Results of our study confirm this supposition. High $\mathrm{H}_{2} \mathrm{O}_{2}$ levels in $\mathrm{PVY}(+)$ compared to virus-free plants suggest a permanent stress reaction induced by the viral particles in plant tissues. In such plants, the virus can move to its upper parts, e.g., leaves. In effect, high $\mathrm{H}_{2} \mathrm{O}_{2}$ levels that were noted may have been responsible for the reduction of root biomass. In the absence of PVY particles in plant tissues, fungi remained the only infectious agent, which had no detectable influence on plant growth and biomass production. The observed significant correlation of increased biomass with increased $\mathrm{H}_{2} \mathrm{O}_{2}$ levels in the roots might be a consequence of intensive cell divisions in this plant organ [29]. 
Beside the observed physiological effects in plants, ultrastructural analysis suggests that mycorrhizal fungi may be involved in the transfer of virus particles within the plant. Xavier and Boyetchko [32] imply that mycorrhizal fungi do not play a role as viral vectors and do not interact with viruses. However, arbuscular mycorrhizal (AM) symbioses were associated with enhanced susceptibility to viruses in earlier reports (reviewed by Whipps [33]). Sipahioglu et al. [14] revealed that the inoculation of PVY-infected potato plants with $G$. intraradices reduced vegetative development but increased viral activity considerably. Transmission of certain viruses by fungal vectors has been previously suggested by Hollings and Stone [34]. However, no sufficient data supporting this hypothesis has been provided so far. The current insufficient knowledge about the epidemiology of diseases caused by plant viruses are in part a consequence of research activities directed solely on the plant-virus interactions, omitting the presence of other plant-associated microorganisms. Our study suggests the presence of PVY particles in arbuscules formed in the roots of $S$. tuberosum inoculated with $G$. intraradices. However, future immunodetection analysis has to confirm this observation, focusing on this specific aspect of the model system. We suppose that beside the growth promotion of virus-infected host plants, the mycorrhizal $G$. intraradices might be a potential vector for plant viruses, which would be highly significant for potato breeding systems and seed potato production, but has to be tested in a subsequent investigation focusing this aspect. Glomus intraradices might protect $S$. tuberosum L. also indirectly by accompanying beneficial bacteria (Fig. 4c). Fig. $4 \mathrm{~d}$ presents the concentration of bacteria in the vicinity of virus-like particles. It is known that endophytic bacteria may induce immunity against some pathogens [8]. Their specific significance in PVY(+) potato plants also still needs further investigation.

It is widely known that studies on multi-component interactions are difficult and laborious, and do not always yield unequivocal results. In our experiment mycorrhizal fungus $G$. intraradices significantly stimulated the growth of PVY-infected potato plants, whereas two saprophytic Trichoderma fungi and a pathogenic strain of C. coccodes had either no effect or inhibitory effect on virus-infected plants. The highest level of $\mathrm{H}_{2} \mathrm{O}_{2}$, an indicator of biotic stress, was recorded in plants inoculated with T. harzianum and C. coccodes, which caused the highest inhibition of plant growth. We are aware that the plant material (one cultivar of potato only) is not sufficient to draw generalized conclusions. However, the present model experiment revealed the potential transfer function of fungal hyphae for both pathogens (like viruses) and plant growth promoting endophytes in potato plants. The verification of these projections is the future challenge of the ongoing research.

\section{Acknowledgments}

This investigation was done in frame of COST action FA1103.

\section{Authors' contributions}

The following declarations about authors' contributions to the research have been made: performed pot experiment and biomass analysis: DT; performed biochemical experiments and participated in the manuscript preparation: ASJ, CB, KM; prepared TEM analysis: KN; supervised the research design and wrote the paper: $\mathrm{KH}$.

\section{References}

1. Syller J, Kaliciak A. Rośliny dziko rosnące jako naturalne źródło wirusów ziemniaka. Post Nauk Roln. 2011;63:21-30. 
2. Karasev AV, Nikolaeva OV, Hu X, Sielaff Z, Whitworth J, Lorenzen JH, et al. Serological properties of ordinary and necrotic isolates of Potato virus Y: a case study of $\mathrm{PVY}^{\mathrm{N}}$ misidentification. Am J Potato Res. 2010;87(1):1-9. http://dx.doi.org/10.1007/s12230-009-9110-2

3. Andret-Link P, Fuchs M. Transmission specificity of plant viruses by vectors. J Plant Pathol. 2005;87(3):153-165.

4. Adams MJ. Epidemiology of fungally-transmitted viruses. Soil Use Manag. 1990;6(4):184-188. http:// dx.doi.org/10.1111/j.1475-2743.1990.tb00833.x

5. Milosevic D, Stamenkovic S, Peric P. Potential use of insecticides and mineral oils for the control of transmission of major aphid-transmitted potato viruses. Pestic Fitomed. 2012;27(2):97-106. http://dx.doi. org/10.2298/PIF1202097M

6. Wojtkowiak-Gębarowska E. Mechanizm zwalczania fitopatogenów glebowych przez grzyby z rodzaju Trichoderma. Postępy Mikrobiol. 2006;45:261-273.

7. Liu J, Maldonado-Mendoza I, Lopez-Meyer M, Cheung F, Town CD, Harrison MJ. Arbuscular mycorrhizal symbiosis is accompanied by local and systemic alterations in gene expression and an increase in disease resistance in the shoots: local and systemic alterations in transcript profiles in AM symbiosis. Plant J. 2007;50(3):529-544. http://dx.doi.org/10.1111/j.1365-313X.2007.03069.x

8. Ara I, Bukhari NA, Aref NM, Shinwari MMA, Bakir MA. Antiviral activities of streptomycetes against Tobacco mosaic virus (TMV) in Datura plant: evaluation of different organic compounds in their metabolites. Afr J Biotechnol. 2014;11(8):2130-2138.

9. Campos-Soriano L, García-Garrido JM, Segundo BS. Activation of basal defense mechanisms of rice plants by Glomus intraradices does not affect the arbuscular mycorrhizal symbiosis. New Phytol. 2010;188(2):597-614. http://dx.doi.org/10.1111/j.1469-8137.2010.03386.x

10. Nawrocka J, Snochowska M, Gajewska E, Pietrowska E, Szczech M, Małolepsza U. Activation of defense responses in cucumber and tomato plants by selected Polish trichoderma strains. Veg Crops Res Bull. 2011;75. http://dx.doi.org/10.2478/v10032-011-0022-6

11. Wehner J, Antunes PM, Powell JR, Mazukatow J, Rillig MC. Plant pathogen protection by arbuscular mycorrhizas: a role for fungal diversity? Pedobiologia. 2010;53(3):197-201. http://dx.doi.org/10.1016/j. pedobi.2009.10.002

12. Nitzan N, Evans M, Johnson DA. Colonization of potato plants after aerial infection by Colletotrichum coccodes, causal agent of potato black dot. Plant Dis. 2006;90(8):999-1003. http://dx.doi.org/10.1094/ PD-90-0999

13. Olko A, Kujawska M. Podwójna rola $\mathrm{H}_{2} \mathrm{O}_{2}$ w odpowiedzi roślin na działanie warunków stresowych. Kosmos. 2011;60(1-2):161-171.

14. Sipahioglu MH, Demir S, Usta M, Akkopru A. Biological relationship of Potato virus Y and arbuscular mycorrhizal fungus Glomus intraradices in potato. Pest Tech. 2009;3:63-66.

15. Bayrami S, Mirshekari B, Farahvash F. Response of potato (Solanum tuberosum cv. Agria) to seed inoculation with mycorrhiza strains in different phosphorus fertilization. J Food Agric Env. 2012;10:726-728.

16. Selosse MA, Baudoin E, Vandenkoornhuyse P. Symbiotic microorganisms, a key for ecological success and protection of plants. C R Biol. 2004;327(7):639-648. http://dx.doi.org/10.1016/j.crvi.2003.12.008

17. Daft MJ, Okusanya BO. Effect of endogone mycorrhiza on plant growth v. influence of infection on the multiplication of viruses in tomato, petunia and strawberry. New Phytol. 1973;72(5):975-983. http:// dx.doi.org/10.1111/j.1469-8137.1973.tb02074.x

18. Shaul O, Galili S, Volpin N, Ginzberg II, Elad Y, Chet I, et al. Mycorrhiza-induced changes in disease severity and PR protein expression in tobacco leaves. Mol Plant Microbe Interact. 1999;12(11):1000-1007. http://dx.doi.org/10.1094/MPMI.1999.12.11.1000

19. Alejo-Iturvide F, Márquez-Lucio MA, Morales-Ramírez I, Vázquez-Garcidueñas MS, Olalde-Portugal V. Mycorrhizal protection of chili plants challenged by Phytophthora capsici. Eur J Plant Pathol. 2007;120(1):13-20. http://dx.doi.org/10.1007/s10658-007-9188-7

20. Nitzan N, Evans MA, Cummings TF, Johnson DA, Batchelor DL, Olsen C, et al. Field resistance to potato stem colonization by the black dot pathogen Colletotrichum coccodes. Plant Dis. 2009;93(11):1116-1122. http://dx.doi.org/10.1094/PDIS-93-11-1116 
21. Vasse J, de Billy F, Truchet G. Abortion of infection during the Rhizobium meliloti-alfalfa symbiotic interaction is accompanied by a hypersensitive reaction. Plant J. 1993;4(3):555-566. http://dx.doi. org/10.1046/j.1365-313X.1993.04030555.x

22. Eaton CJ, Cox MP, Scott B. What triggers grass endophytes to switch from mutualism to pathogenism? Plant Sci. 2011;180(2):190-195. http://dx.doi.org/10.1016/j.plantsci.2010.10.002

23. Miozzi L, Catoni M, Fiorilli V, Mullineaux PM, Accotto GP, Lanfranco L. Arbuscular mycorrhizal symbiosis limits foliar transcriptional responses to viral infection and favors long-term virus accumulation. Mol Plant Microbe Interact. 2011;24(12):1562-1572. http://dx.doi.org/10.1094/MPMI-05-11-0116

24. Luo Y, Zhang DD, Dong XW, Zhao PB, Chen LL, Song XY, et al. Antimicrobial peptaibols induce defense responses and systemic resistance in tobacco against tobacco mosaic virus: peptaibols induce plant resistance against TMV. FEMS Microbiol Lett. 2010;313(2):120-126. http://dx.doi. org/10.1111/j.1574-6968.2010.02135.x

25. Otulak K, Garbaczewska G. Localisation of hydrogen peroxide accumulation during Solanum tuberosum cv. Rywal hypersensitive response to Potato virus Y. Micron. 2010;41(4):327-335. http://dx.doi.org/10.1016/j. micron.2009.12.004

26. Alkan N, Davydov O, Sagi M, Fluhr R, Prusky D. Ammonium secretion by Colletotrichum coccodes activates host NADPH oxidase activity enhancing host cell death and fungal virulence in tomato fruits. Mol Plant Microbe Interact. 2009;22(12):1484-1491. http://dx.doi.org/10.1094/MPMI-22-12-1484

27. Mathieu Y, Jouanneau JP, Thomine S, Lapous D, Guern J. Cytosolic protons as secondary messengers in elicitor-induced defence responses. Biochem Soc Symp. 1994;60:113-130.

28. Britto DT, Kronzucker HJ. $\mathrm{NH}_{4}^{+}$toxicity in higher plants: a critical review. J Plant Physiol. 2002;159(6):567584. http://dx.doi.org/10.1078/0176-1617-0774

29. Torres MA. Reactive oxygen species signaling in response to pathogens. Plant Physiol. 2006;141(2):373-378 http://dx.doi.org/10.1104/pp.106.079467

30. Santos R, Hérouart D, Sigaud S, Touati D, Puppo A. Oxidative burst in alfalfa-Sinorhizobium meliloti symbiotic interaction. Mol Plant Microbe Interact. 2001;14(1):86-89. http://dx.doi.org/10.1094/ MPMI.2001.14.1.86

31. Gapper C. Control of plant development by reactive oxygen species. Plant Physiol. 2006;141(2):341-345. http://dx.doi.org/10.1104/pp.106.079079

32. Xavier LJC, Boyetchko SM. Arbuscular mycorrhizal fungi as biostimulants and bioprotectants of crops. In: Khachatourians GG, Arora DK, editors. Applied Mycology and Biotechnology. Amsterdam: Elsevier; 2002. p. 311-340. ( $\operatorname{vol} 2$ ).

33. Whipps JM. Prospects and limitations for mycorrhizas in biocontrol of root pathogens. Can J Bot. 2004;82(8):1198-1227. http://dx.doi.org/10.1139/b04-082

34. Hecht EI, Bateman DF. Non-specific acquired resistance to pathogens resulting from localised infections by Thielaviopsis basicola on viruses in tobacco leaves. Phytopathology. 1964;54:523-530. 